\title{
O INGLÊS É PRECISO...
}

Viebig RG, Pardini F. O inglês é preciso.

DESCRITORES - Artigo de revista. Publicações periódicas como assunto. Redação. Disseminação de informação. Internacionalidade.

Recentemente fomos questionados quanto à mudança das normas da Revista ao aceitar novas submissões somente na língua inglesa. Com esta decisão, os ARQUIVOS de GASTROENTEROLOGIA estariam negando a chance a alguns colegas que não dominam o idioma inglês de se atualizarem e que esta medida desestimularia a submissão de seus trabalhos às novas normas, pois além da preocupação com o conteúdo, os autores estariam ocupados com sua tradução.

A revista ARQUIVOS de GASTROENTEROLOGIA tem 46 anos de existência, com publicação ininterrupta, o que para uma revista científica de entidade privada já representa distinção significativa. A pretensão dos gestores atuais é de que ela permaneça viva e atuante pelo menos por período semelhante. Durante esta última década mantivemos nossa filosofia de publicação independente, modernizando sua diagramação e mantendo-nos fiéis aos princípios de seu fundador Prof. José Fernandes Pontes - , qual seja, um veículo de difusão da pesquisa científica na Gastroenterologia e de suas ramificações, procurando estimular e encorajar os médicos brasileiros a aprimorar suas publicações.

A ARQUIVOS tem as mesmas aspirações e pretensões da Comissão Editorial de outras publicações científicas, porém no contexto de nossa realidade. Qualquer trabalho a nós enviado é passível de publicação. Os editores esforçam-se em emitir pareceres justificados, no intuito de opinar, sugerir, corrigir e aprimorar os trabalhos candidatos à publicação. Não é nossa premissa simplesmente recusá-los de forma lacônica, como o fazem muitas publicações estrangeiras de renome. Para ser publicado, o trabalho deve estar acordo com as normas editoriais, obedecer aos preceitos atuais da pesquisa científica, que, além da ética e consentimento informado, deve ter aprovações de Comitê de Ética em Pesquisa. Os estudos também devem ser aprovados por pelo menos dois revisores especialistas do tema, que avaliam-no com caráter sigiloso e anônimo. Precipuamente seu conteúdo deve ser de interesse científico e que acrescente informações ao conhecimento médico.

A adesão ao SciELO há 9 anos já demonstrava não só a necessidade de estar filiada aos novos meios de comunicação, assim como o interesse de ter maior visibilidade e FATOR DE IMPACTO. Este último termo tem comprometido o sono dos editores da revista e a meta a ser alcançada é o "fator de impacto" cada vez maior e, as ações decorrentes, são similares a uma corrida de automóveis, em que todos os meios técnicos são utilizados para se atingir melhores índices. É uma corrida injusta, pois revistas como a nossa competem com verdadeiros bólidos, superajustados e superpatrocinados que, além de receber insumos de entidades ou de anunciantes, têm a preferência dos autores. Nada mais justo que trabalhos importantes sejam lidos em revistas de grande porte e circulação, o que não garantiria que, uma vez publicado em periódico de alta relevância, seu conteúdo científico seja realmente plausível. Não é preciso citar, mas sabe-se a respeito de revistas de altíssimo impacto que recentemente publicaram ensaios com resultados duvidosos e não confiáveis.

Para ser publicado o trabalho científico também deve primordialmente acrescentar algo novo ao conhecimento e o desejo de seus autores é que, além de sua repercussão junto à comunidade afim, também deve ser referenciado por outros autores. Os novos critérios do Qualis exigem que nossa revista promova sua melhoria constante em relação ao "fator de impacto", pois com isto possibilita-se sua integração ao chamado grupo de revistas do ISI (Institute for Scientific Information), condição imprescindível para manutenção de sua existência e pareamento junto à demais publicações nacionais. O que promove uma revista junto ao ISI é a quantidade de citações que ela gera nas demais, e para isto ocorrer, além da qualidade dos trabalhos nela publicados, precisa ter visibilidade e ser lida.

Para continuarmos nossa jornada por mais algumas décadas devemos acompanhar as tendências mundiais. A globalização do conhecimento é fato constatado e, qualquer termo digitado em um mecanismo de busca no computador, gera milhares de citações e, certamente nos sentiríamos muito frustrados como cientistas, quando, ao digitar o termo ou a palavra-chave de nossa pesquisa, não fôssemos destacados na primeira página de citações, mesmo com a consciência de sua relevância científica.

Não é suficiente apenas a publicação de resumos e palavras-chave em inglês. Na verdade, o resumo é essencial para atrair a curiosidade de outros pesquisadores, mas é fundamental que o texto seja publicado em língua 
inglesa, caso contrário, certamente não deverá ser lido ou sequer citado. Temos que nos curvar para a tendência mundial de que o inglês é idioma oficial de congressos internacionais, das publicações e das comunicações em geral. $\mathrm{O}$ argumento final para justificar sua publicação baseia-se na simples verificação das referências desta e de outras revistas ao final de um trabalho. A maioria é publicada em língua inglesa, seja de autor nacional ou estrangeiro.

Desde o início deste ano a revista ARQUIVOS somente aceita submissão de trabalhos em inglês. Alguns artigos ainda serão publicados em português por terem sido apresentados nesta língua. Os artigos de Revisão e Atualização e os do
Fórum do Jovem Pesquisador, escritos por convidados, continuarão a ser publicados em português, pois a intenção é promover o conhecimento para os novos especialistas. Aconselhamos aos autores o treinamento da escrita de textos em inglês e que sempre revisem-nos por pessoa versada em inglês médico e não o coloquial, uma vez que o número de erros e impropriedades cometidos pelos autores em tal idioma, ainda é significativo, mesmo que se tenha uma prática coloquial de seu uso.

Ricardo Guilherme VIEBIG ${ }^{1}$ Fernando PARDINI ${ }^{2}$

Viebig RG, Pardini F. The English language is necessary... Arq Gastroenterol. 2009;46(3):162-3.

HEADINGS - Journal article. Periodicals as topic. Writing. Information dissemination. Internacionality. 